DEVELOPMENT, INSTALLATION, AND OPERATION OF A FLOOD-MONITORING

SYSTEM IN SOMERSET COUNTY, NEW JERSEY

By Paul Dunne and Anthony J. Velnich

U.S. GEOLOGICAL SURVEY

Open-File Report 94-65

Prepared in cooperation with the

SOMERSET COUNTY BOARD OF CHOSEN FREEHOLDERS

West Trenton, New Jersey

1994 


\section{U.S. DEPARTMENT OF THE INTERIOR \\ BRUCE BABBITT, Secretary}

U.S . GEOLOGICAL SURVEY

Gordon P. Eaton, Director

For additional information write to:

District Chief

U.S. Geological Survey Mountain View Office Park 810 Bear Tavern Road

West Trenton, NJ 08628
Copies of this report can be obtained from:

U.S. Geological Survey Earth Science Information Center Open-File Reports Section Box 25286, MS 517

Denver Federal Center Denver, CO 80225 


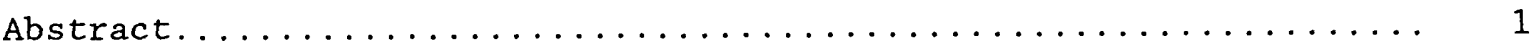

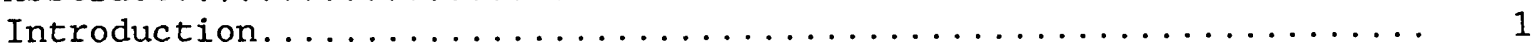

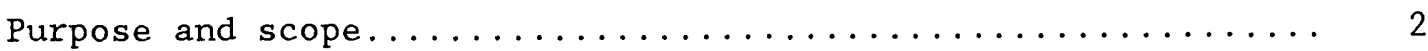

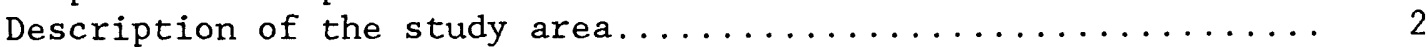

Previous investigations.......................... 2

History of flood-monitoring systems in New Jersey........... 5

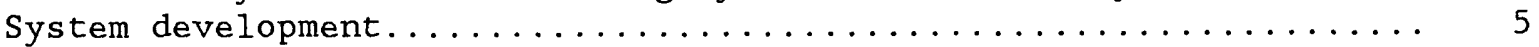

Very high frequency radio-communication link............. 6

Ultra high frequency radio-communication link............. 10

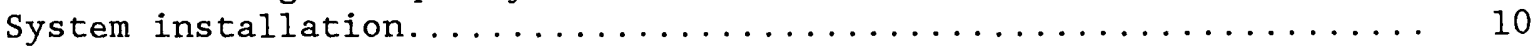

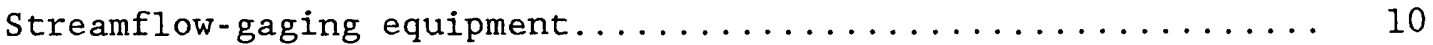

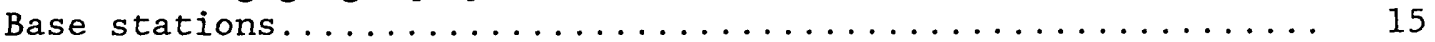

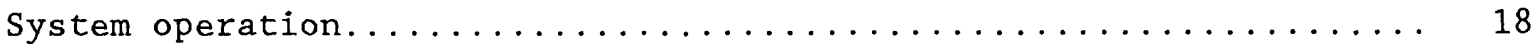

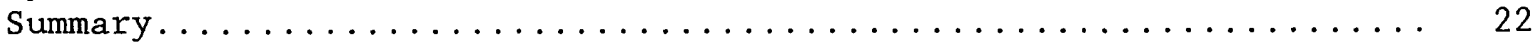

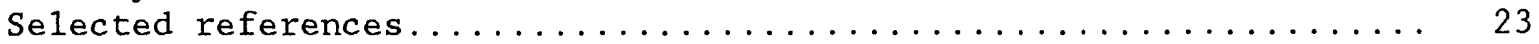

\section{ILLUSTRATIONS}

Figure 1. Map showing physiographic provinces in

Somerest County, New Jersey.................

2. Map showing major drainage basins in Somerset County, New Jersey........................... 4

3. Map showing location of streamflow gages equipped with telemetry in Somerset County, New Jersey.......... 8

4. Map showing location of rain gages equipped with telemetry in Somerset County, New Jersey........... 9

5. Diagram showing the very high frequency radio stream-

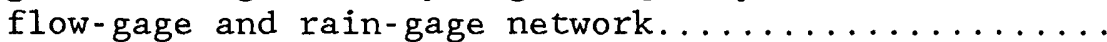

6. Diagram showing the ultra high frequency radio base-

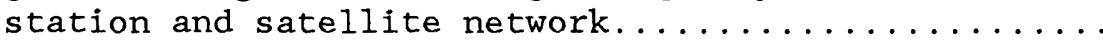

7. Photograph showing a gage house at North Branch Raritan River near Far Hills, New Jersey............... 13

8. Diagram of an installed rain gage................. 14

9. Diagram of an installed float/level streamflow gage.... 16

10. Photograph showing the U.S Geological Survey base

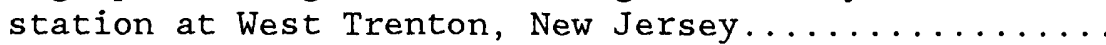

11. Example of computer output showing rainfall data across Somerset County, New Jersey, collected during the 24-hour period, December 11, 1992.............

12. Example of computer output showing streamflow gage height as a function of time from November 1-5, 1992, at Stony Brook at North Plainfield, New Jersey......

\section{TABLES}

Table 1. Description of rain gages and streamflow gages in the Somerset County flood-monitoring system............

2. Example of computer retrieval of real-time gage-height data collected on May 31, 1992, at Somerville, New

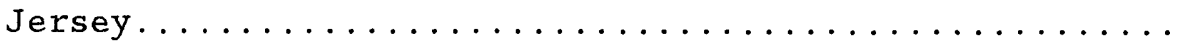


Multiply

inch (in.)

foot ( $f t)$

mile (mi)

square mile $\left(m i^{2}\right)$

cubic foot per second $\left(f t^{3} / s\right)$
By

25.4

0.3048

1.609

2.590

0.02832
To obtain

millimeter

meter

kilometer

square kilometer

cubic meter per second

Sea level: In this report "sea level" refers to the National Geodetic Vertical Datum of 1929--a geodetic datum derived from a general adjustment of the first-order level nets of the United States and Canada, formerly called Sea Level Datum of 1929. 


\title{
DEVELOPMENT, INSTALLATION, AND OPERATION OF A FLOOD-MONITORING SYSTEM IN SOMERSET COUNTY, NEW JERSEY
}

By Paul Dunne and Anthony J. Velnich

\begin{abstract}
During 1978-90, the flood-monitoring system in Somerset County, New Jersey, consisted of eight streamflow gages equipped with rain gages. Beginning in 1990, the system, which is operated by the U.S. Geological Survey for the county, was expanded and updated to include 22 streamflow gages and 22 rain gages. Originally, gages were equipped with telephone telemetry which provided data only when telephoned. The telephone telemetry was replaced with a radio network that provides immediate or real-time data to the county. The system also has built-in alarm features which are activated by various conditions.
\end{abstract}

A variety of streamflow gages and rain gages are in use throughout the county. Three repeaters and a computer base station receive and transmit data to the U.S. Geological Survey office in West Trenton, New Jersey, where the data is stored in a computer data base. The expanded network has improved the spatial coverage across Somerset County which, along with the real-time data collection, has improved the monitoring of local rainfall and floods.

\section{INTRODUCTION}

During the last 25 years (1968-1992), small streams in Somerset County, New Jersey, have flooded with increasing frequency. Flooding of the large streams, such as the Raritan and Millstone Rivers, has been predicted reliably; however, flooding of the small streams, especially in urban areas, is difficult to predict and is a critical problem in the county. As the county becomes increasingly urbanized, the flooding may cause extensive property damage, and this flooding problem will become more critical.

During 1978-90, eight rain gages and eight streamflow-gaging stations with telephone telemetry were in operation across Somerset County at Holland Brook at Readington, North Branch Raritan River near Far Hills, Peter's Brook near Raritan, Pike Run at Belle Mead, Royce Brook Tributary near Belle Mead, West Branch Middle Brook near Martinsville, Green Brook at Seeley Mills, and East Branch Stony Brook at Best Lake at Watchung. Although these stations provided streamflow data at points upstream from the problem areas, they were useful only when telephoned regularly and did not provide data that could be used to develop estimates of peak stages at critical points downstream.

The U.S. Geological Survey (USGS), in cooperation with the Somerset County Board of Chosen Freeholders, conducted a study of the flood monitoring network in Somerset County. During this study, additional streamflow-gaging stations were installed in critical flood-prone areas. 
Additional rain gages were installed to expand the real-time collection of rainfall data and to extend the spatial coverage of rainfall data over the entire basin, increasing the probability that local rainfall and flooding will not be overlooked. The additional gages will increase the data base of long-term records.

\section{Purpose and Scope}

This report describes the flood-monitoring system in Somerset County, New Jersey. Locations of the 22 streamflow gages and 22 rain gages that constitute the monitoring network are presented. Three aspects of the Somerset County Flood-Monitoring System are discussed (1) the development of the system, including the selection of streamflow gage and rain gage sites and the radio telemetry network, (2) the installation of the expanded network with a description of the gaging equipment, and (3) the operation of the system.

\section{Description of the Study Area}

The study area, Somerset County, covers $307 \mathrm{mi}^{2}$ in north-central New Jersey (Campbe11, 1987). Most of the county lies within the Piedmont Physiographic Province (Fenneman, 1938) (fig. 1), which is underlain by shales, siltstones, and sandstones of Triassic and Jurassic age and igneous basalt extrusions and diabase intrusions of Jurassic age (Wolfe, 1977). The sedimentary rocks form a broad, gently rolling lowland with an average elevation of 200 to $400 \mathrm{ft}$ above sea level. Three mountains in the Piedmont Physiographic Province lie within Somerset County. The First and Second Watchung Mountains in the northeastern part of Somerset County consist mainly of basaltic lava flows, and Sourland Mountain in the southwestern part of the county consists mainly of diabase intrusions.

A small part of the county lies within the New England Physiographic Province. The highlands of the province are underlain chiefly by Precambrian gneisses and schists, whereas the valleys are underlain by fault-block inliers of Paleozoic limestone and shale (Wolfe, 1977). The elevation of the highlands ranges from 1,000 to $1,500 \mathrm{ft}$ above sea level; the elevation of the valleys ranges from 500 to $800 \mathrm{ft}$ above sea level.

Five major drainage basins lie partly within Somerset County: Raritan River (mainstem), covers $77 \mathrm{mi}^{2}$; Millstone River, $100 \mathrm{mi}^{2}$; North Branch Raritan River, $64 \mathrm{mi}^{2}$; South Branch Raritan River, $26 \mathrm{mi}^{2}$; and the Passaic River, $38 \mathrm{mi}^{2}$ (fig. 2). (Square miles from Campbell (1987) are approximate.)

\section{Previous Investigations}

Campbel1 (1987) presented rainfall-runoff data for eight drainage basins in Somerset County for water years 1980 through 1984. (A water year is the 12 -month period beginning October 1 and ending September 30 . It is designated by the year in which it ends.) The data were measured at 5minute intervals, and the data were stored in computer files. Rainfall was measured at two sites within each drainage basin. 


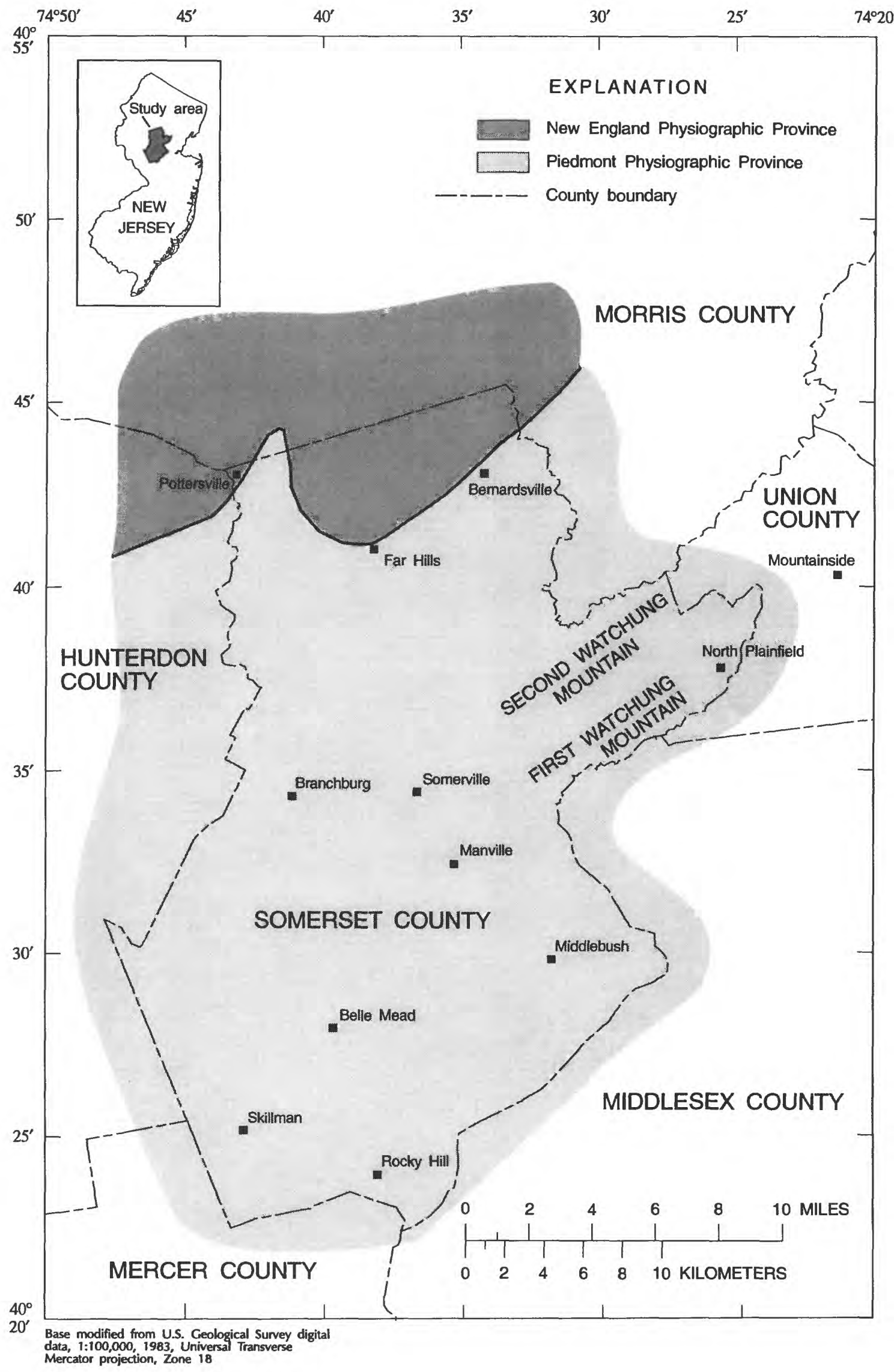

Figure 1.--Physiographic provinces in Somerset County, New Jersey. 


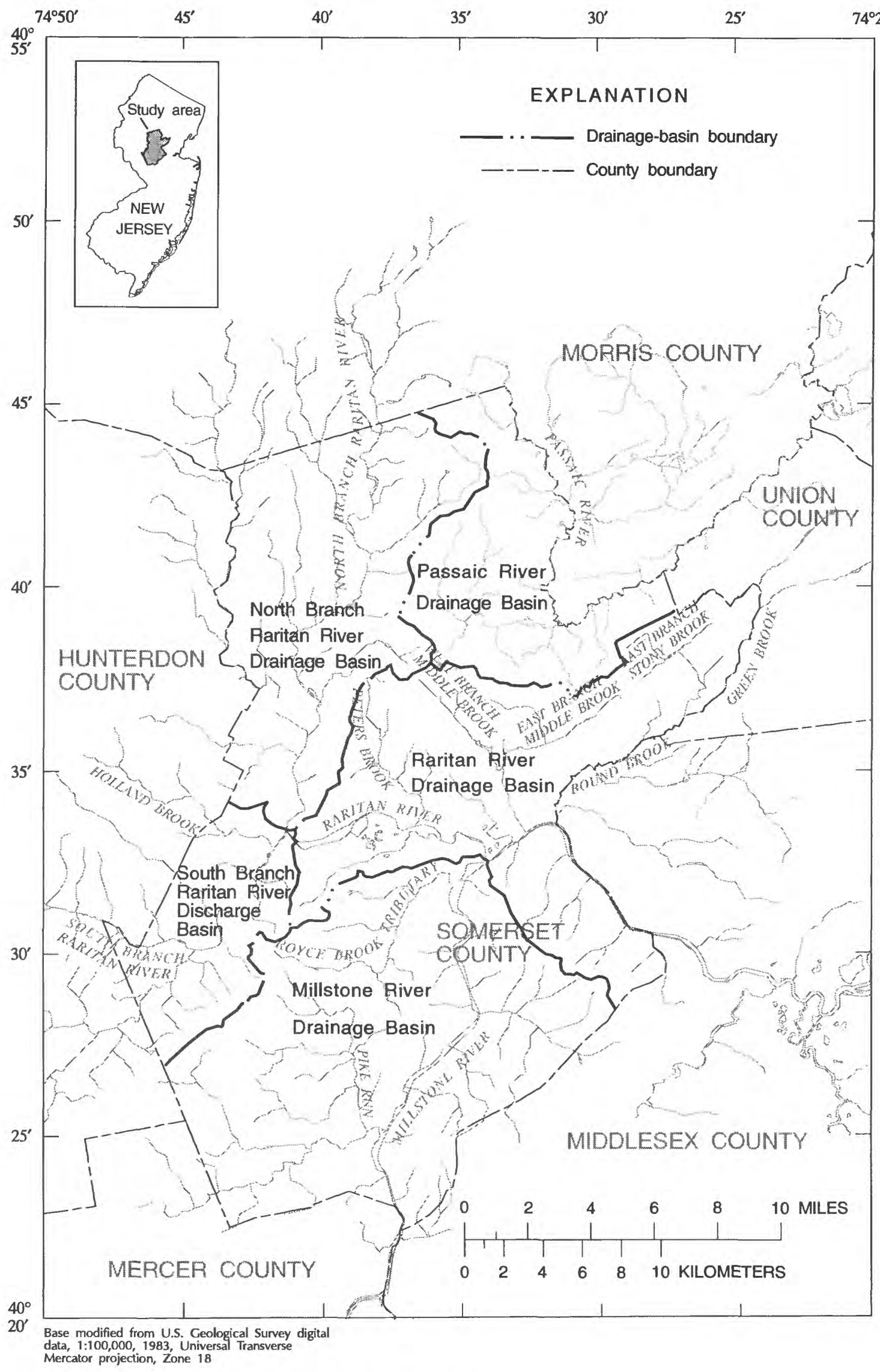

Figure 2.--Major drainage basins in Somerset County, New Jersey. 
Fulton (1990) calibrated a distributed-routing rainfall-runoff model for the same eight drainage basins in Somerset County. Five-minute precipitation data for 448 storms that occurred during 1914-79 at Trenton, New Jersey, and daily precipitation data collected at Trenton, New Jersey, were used to calibrate the model. Results of model verification indicated efficiencies of 75 to 93 percent for storm volumes and 65 to 93 percent for peak flows (Fulton, 1990).

\section{History of Flood-Monitoring Systems in New Jersey}

In 1971 and 1973, severe floods caused major property damage and the loss of six lives in Somerset County (Stankowski, 1972; Stankowski and Velnich, 1974). These floods highlighted the need for a flood-monitoring and warning system for the county (Joseph Skupien, Somerset County Department of Public Works, written commun., 1990). The National Weather Service (NWS) in cooperation with the Green Brook Flood Control Commission installed a rain gage in North Plainfield and two flash-flood alarms, one on Green Brook at Seeley Mills and one on Stony Brook at Watchung. These alarms are still in operation and sound at a local police station when the streams reach a preset stage. The rain gage transmits data only when manually activated by telephone.

In 1978, New Jersey's first local flood-warning system was installed by the USGS in Somerset County (Schopp and Burns, 1991). This system consisted of a network of eight streamflow-gaging stations equipped with rain gages. The purpose of the streamflow-gaging stations was to collect rainfall-runoff data, which in turn would improve flood-monitoring and flood-frequency estimating techniques.

The Passaic Flood Warning System (PFWS), which was completed in 1988, is the second local flood-warning system in New Jersey. This system consists of 31 rain gages, 18 streamflow-gaging stations, and 11 basestation computers (Schopp and Burns, 1991).

\section{SYSTEM DEVELOPMENT}

In early 1990, the telephone telemetry of the first network was replaced with radio links between each gaging station and the base station located at the Somerset County Engineer's office. A computer analysis was conducted by NWS to determine radio communication paths (Steve Francis, National Weather Service, written commun., 1988). Some of the original telephone telemetry is still operational and is used as a backup to the radio telemetry. Five streamflow gages and three rain gages are equipped with telephone telemetry, which is operated by NWS and activated by the base-station computer.

Before 1990, streamflow gages typically were located upstream of floodprone areas and were useful only when telephoned regularly. The eight streamflow gages and eight rain gages were not adequate to monitor flood conditions across the county. A larger network of gages would improve the likelihood that flood conditions would not be overlooked; therefore, five streamflow-gaging stations and ten rain gages were added to the network. 
The new streamflow gages were placed at critical flood-prone locations to provide real-time indications of imminent flooding. Radio communication links provided continuous reports on streamflow, which aided in monitoring flood conditions. The additional rain gages were placed throughout the county to increase the information on heavy precipitation. The network was also expanded by adding five NWS streamflow gages, one PFWS streamflow gage, and one PFWS rain gage. In 1993, three additional streamflow gages were installed to bring the present total of streamflow gages and rain gages to 22 each. Site locations are listed in table 1.

The base-station computer, located at the Somerset County Engineering division in the Somerset County Administration Building in Somerville, New Jersey, receives the streamflow and rainfall data by very high frequency (VHF) radio link and telephone through a desk-top microcomputer and uses a software configuration to $\log$ the incoming data.

The Somerset County base-station computer is linked by ultra high frequency (UHF) radio to an independent base-station computer at the USGS office in West Trenton, New Jersey. Streamflow and rainfall data measured by the Somerset County gages, as well as some streamflow and rainfall data from PFWS, are sent to the USGS office from Somerset County's base-station computer at 15-minute intervals. The USGS also provides additional streamflow and rainfall data to Somerset County by the same UHF radio link. Somerset County's streamflow and rainfall telemetry sites are shown in figures 3 and 4 , respectively.

Each streamflow and rainfall gage is equipped with data transmitters and sensors. The radios are powered by 12 -volt batteries and are designed to transmit an 8-watt, formatted phase shift keyed (PSK) signal to the basestation receiver. Where terrestrial interference, such as hills or buildings, hinders direct reception, the streamflow and rainfall data are passed through repeaters which retransmit the data. The Somerset County network has two VHF repeaters--one on Sourland Mountain and one on the Elizabethtown Water Tank. Three streamflow and three rainfall gages located in the northeastern part of the study area pass data through repeaters operated by the PFWS and relay the data to the Somerset County base-station computer.

\section{Very High Frequency Radio-Communication Link}

Two Federal radio frequencies reserved for hydrologic data are used in the data network (169.5 $\mathrm{MHz}$ (megahertz) and $171.1 \mathrm{MHz}$ ). The streamflow and rainfall data are sent over the VHF band at 160 to $174 \mathrm{MHz}$, which is optimal for 20 to 25-mile-long links. Each channel is spaced 2,700 $\mathrm{Hz}$ (hertz) apart, providing a bandwidth suitable for short duration transmission of data. The data transmitters, which are event counters, are equipped with internal accumulators. Thus, if one data report is missed, the next or subsequent transmission received by the base station will represent the total change during the period. The short duration of each transmission is such that 3,000 transmissions per hour can be received by each base station. 
Table 1.--Description of rain gages and streamflow gages in the Somerset County flood-monitoring system

[MHz, Megahertz; T, telephone telemetry; .. no gage at that site; , not transmitted; USGS, U.S.

Geological Survey; PFWS, Passaic Flood Warníng system; NWS, Nat ional Weather Service; PR, Privately Owned]

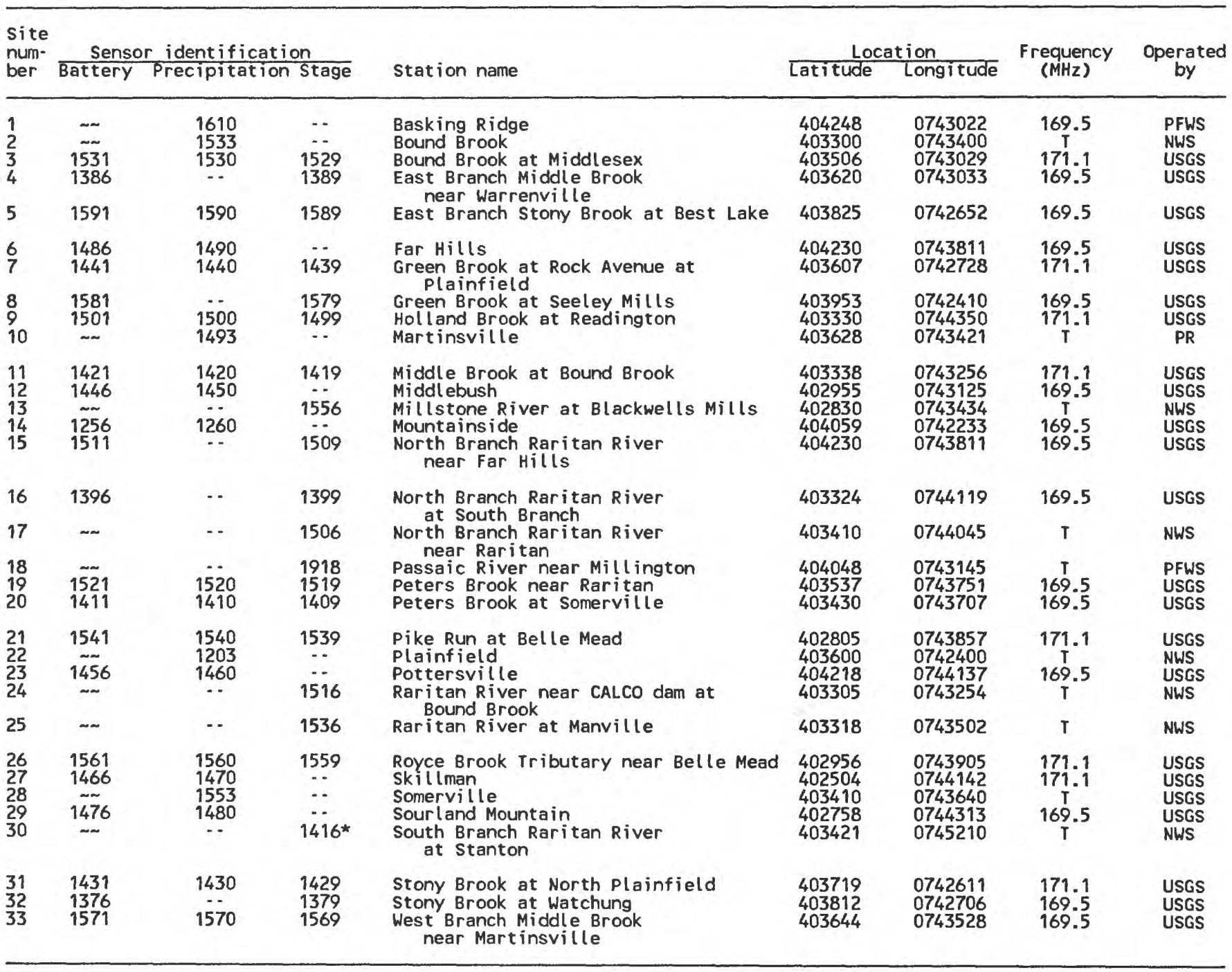




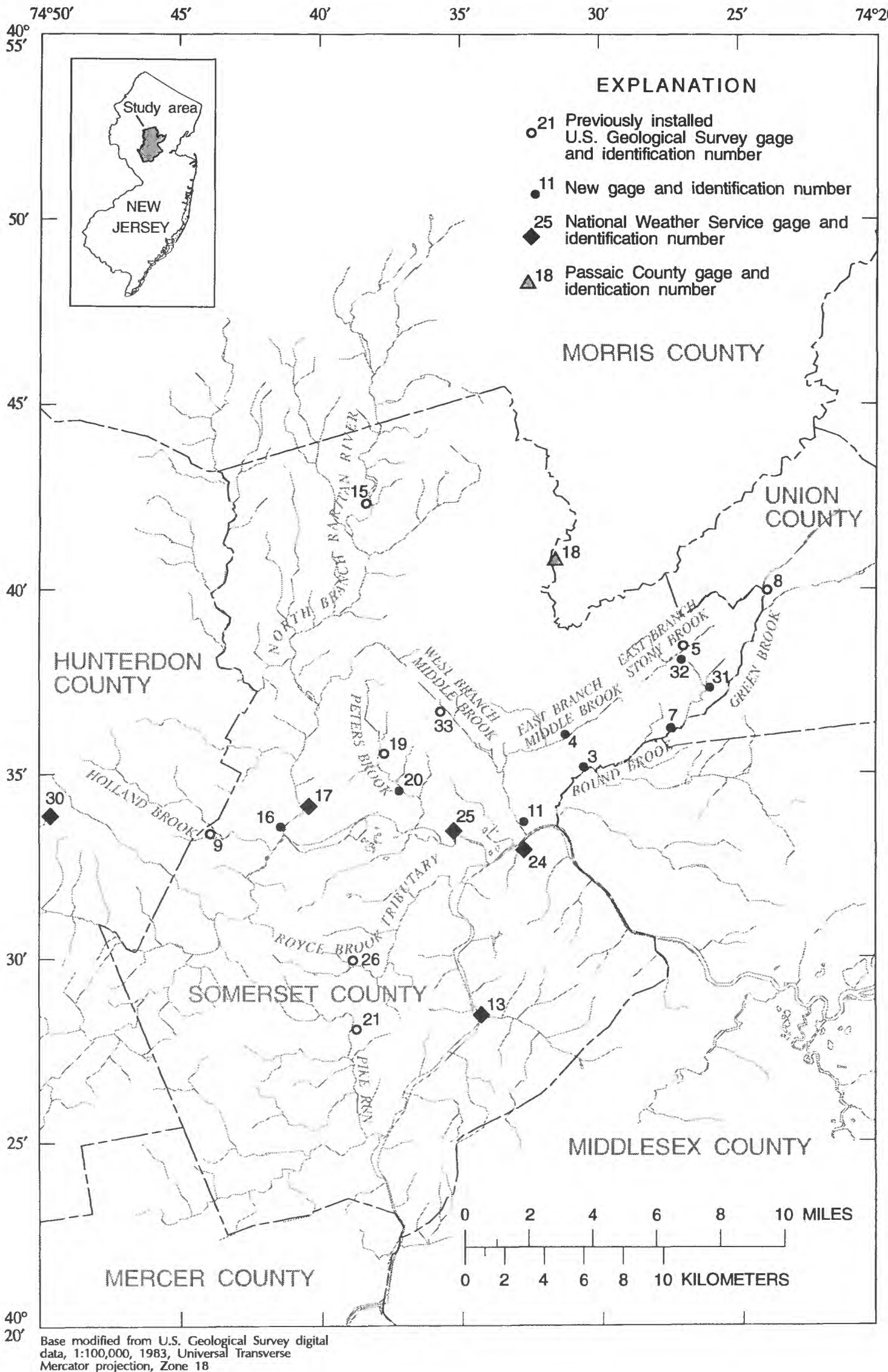

Figure 3.--Location of streamflow gages equipped with telemetry in Somerset County, New Jersey. (Numbers refer to table 1.) 


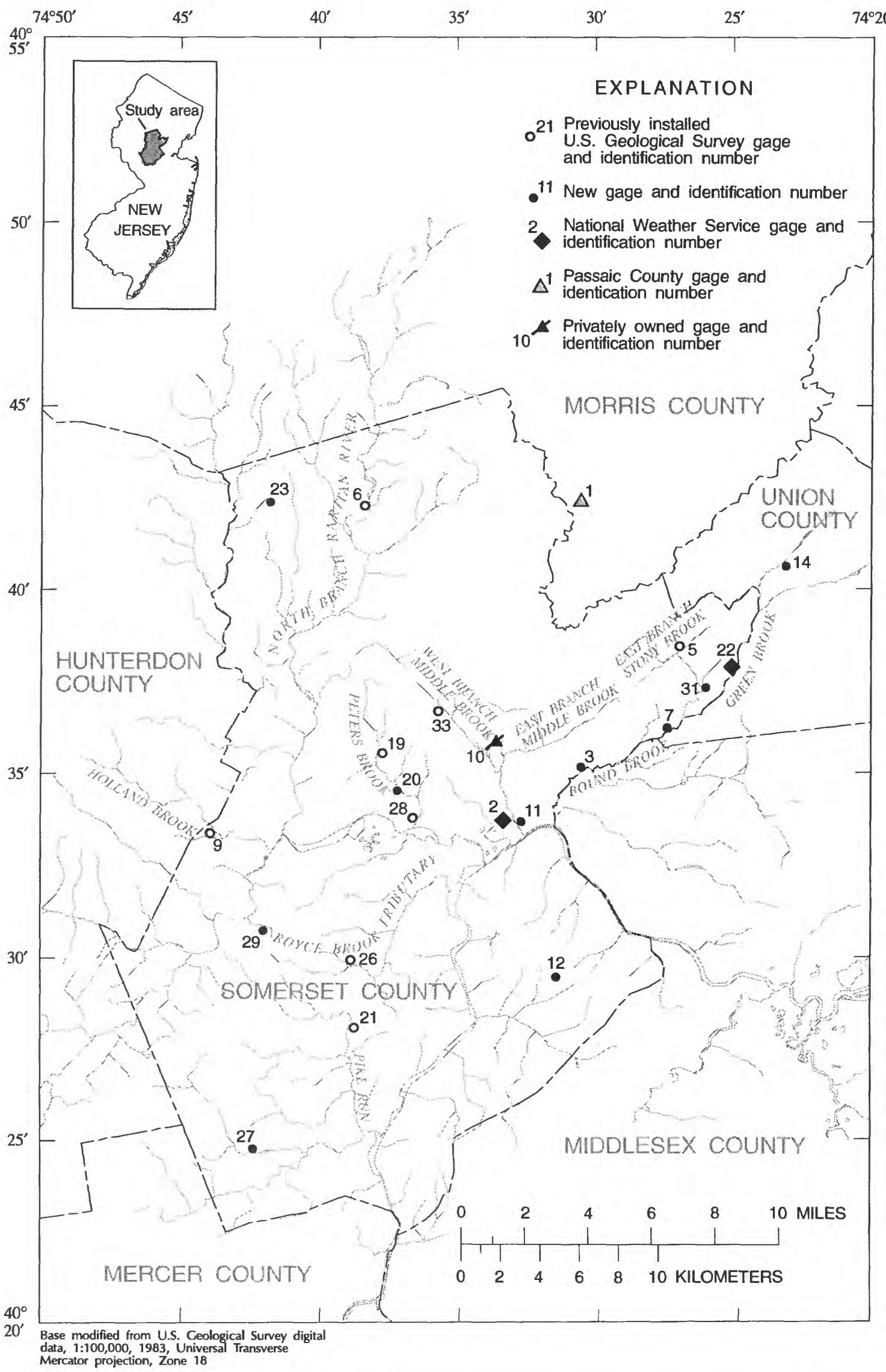

Figure 4.--Location of rain gages equipped with telemetry in Somerset County, New Jersey. (Numbers refer to table 1.) 
The system is designed so that 200 sensors can be used on each incoming frequency with minimal loss of data. Each streamflow-gage site may have a stage sensor or a rain gage, or both. The transmitters have the ability to send daily measurements of battery voltage for maintenance purposes. The two repeaters, which operate on the VHF band, are the "store and forward" type that receive the streamflow and rainfall data, check for proper identification, eliminate erroneously formatted data and noise, and retransmit the data to another repeater or base station. The VHF network is shown in figure 5 .

\section{U1tra High Frequency Radio-Communication Link}

Base stations communicate on the UHF radio band frequency of 412.775

$\mathrm{MHz}$. The UHF band is not as susceptible to interference and produces less skip off the upper atmosphere than the VHF radio band, creating less interference outside the network. The base station at the USGS is a part of the larger PFWS maintained by the New Jersey Department of Environmental Protection and Energy (NJDEPE). The PFWS includes a UHF network and a commercial satellite link to the NWS offices in State College, $\mathrm{Pa}$, and Philadelphia, $\mathrm{Pa}$., as shown in figure 6 . The base stations at the New Jersey State Police and NJDEPE can receive forecasts, warnings, data, and messages from the NWS through this satellite link. These base stations can relay any information from the NWS to other base stations through the UHFradio paths.

\section{SYSTEM INSTALLATION}

\section{Streamflow-gaging Equipment}

A variety of sensors and equipment are currently (1993) in operation in Somerset County--streamflow gages, such as punched paper tape recorders activated by float/level sensors and rain gages, tipping-bucket rain gages, weighing-bucket rain gages, and float-activated rain gages. The equipment is kept in gage houses (fig. 7) for security purposes at Peters Brook, West Branch Middle Brook, Pike Run, Holland Brook, Royce Brook tributary, and East Branch Stony Brook. Rain gages are located at the North Branch Raritan and Green Brook near Far Hills and Mountainside, respectively.

New streamflow gages are located on West Branch Middle Brook, Green Brook, Stony Brook, Peters Brook, North Branch Raritan River, East Branch Middle Brook, and Bound Brook. A float/level sensor mounted in a 12-in. stilling well with a tipping-bucket rain gage is connected to a data transmitter at each site. To provide additional rainfall data for the county, six stand-alone rain gages were installed at Far Hills, Mountainside, Middlebush, Skillman, Pottersville, and Sourland Mountain.

A typical stand-alone rain gage with transmitter and antenna is shown in figure 8. This gage has an inside diameter of $12 \mathrm{in.}$ and stands about 10 $\mathrm{ft}$ high. The transmitter is located in the standpipe about $2 \mathrm{ft}$ below land surface for security and temperature stability. The entire package is set in concrete and topped by a funnel with a screen to catch debris. The tipping bucket, located below the funnel, tips after 1 millimeter (about 0.04 inches) of rain is collected. Each tip is counted but will be 


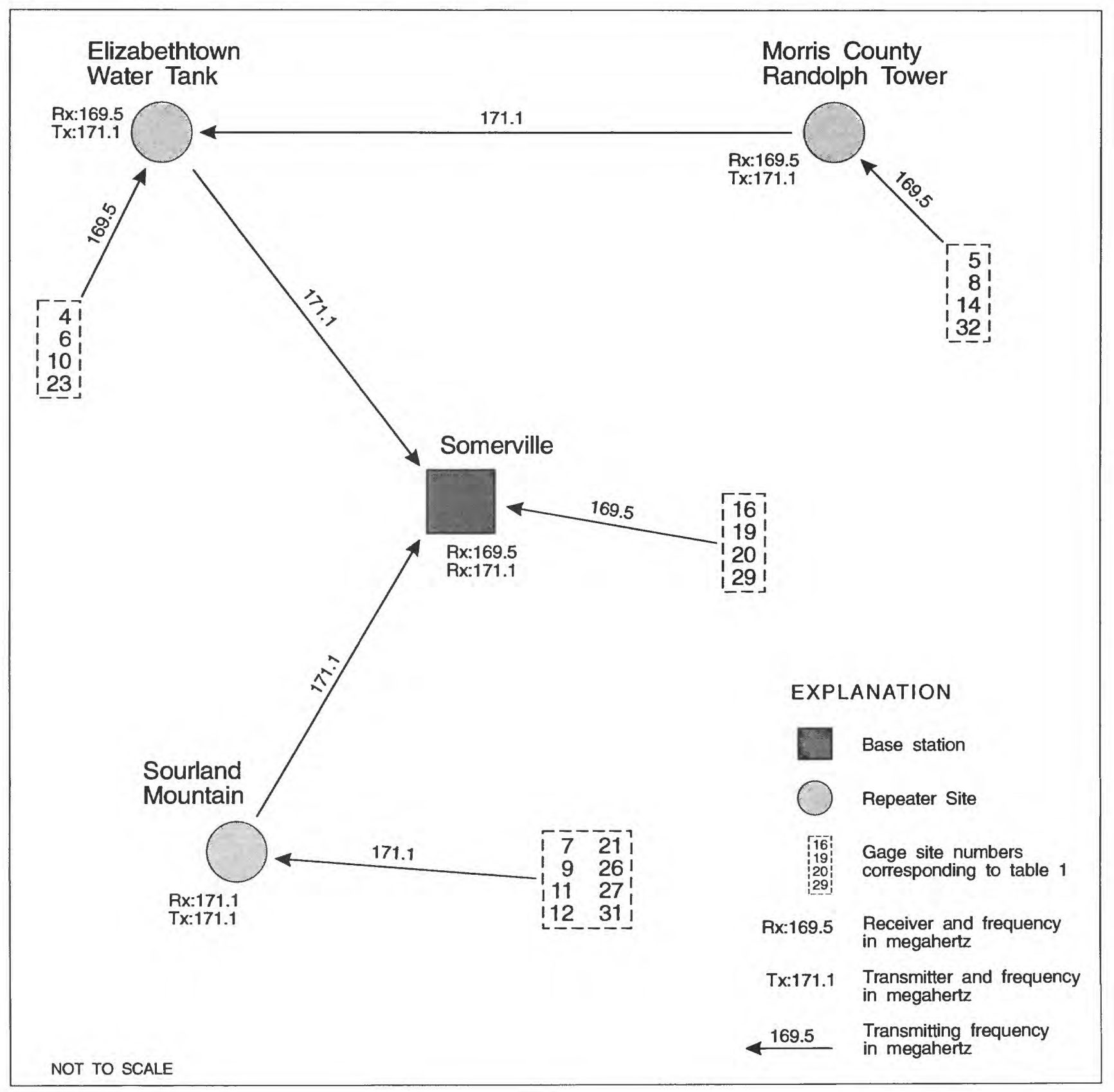

Figure 5.--Diagram showing the very high frequency radio streamflow-gage and rain-gage network. 


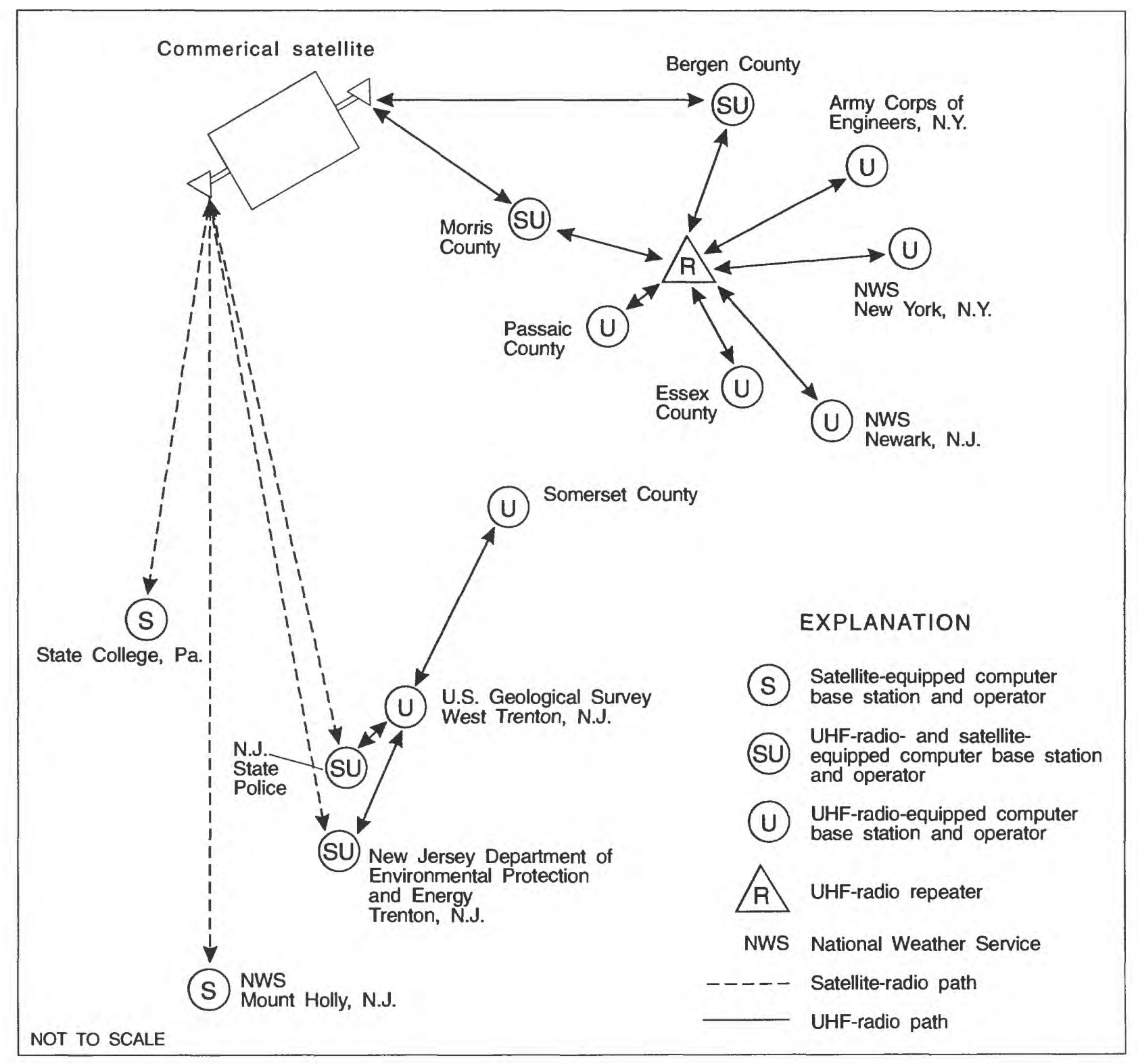

Figure 6.--Diagram showing the ultra high frequency radio base-station and satellite network (Modified from Schopp and Burns, 1991). 


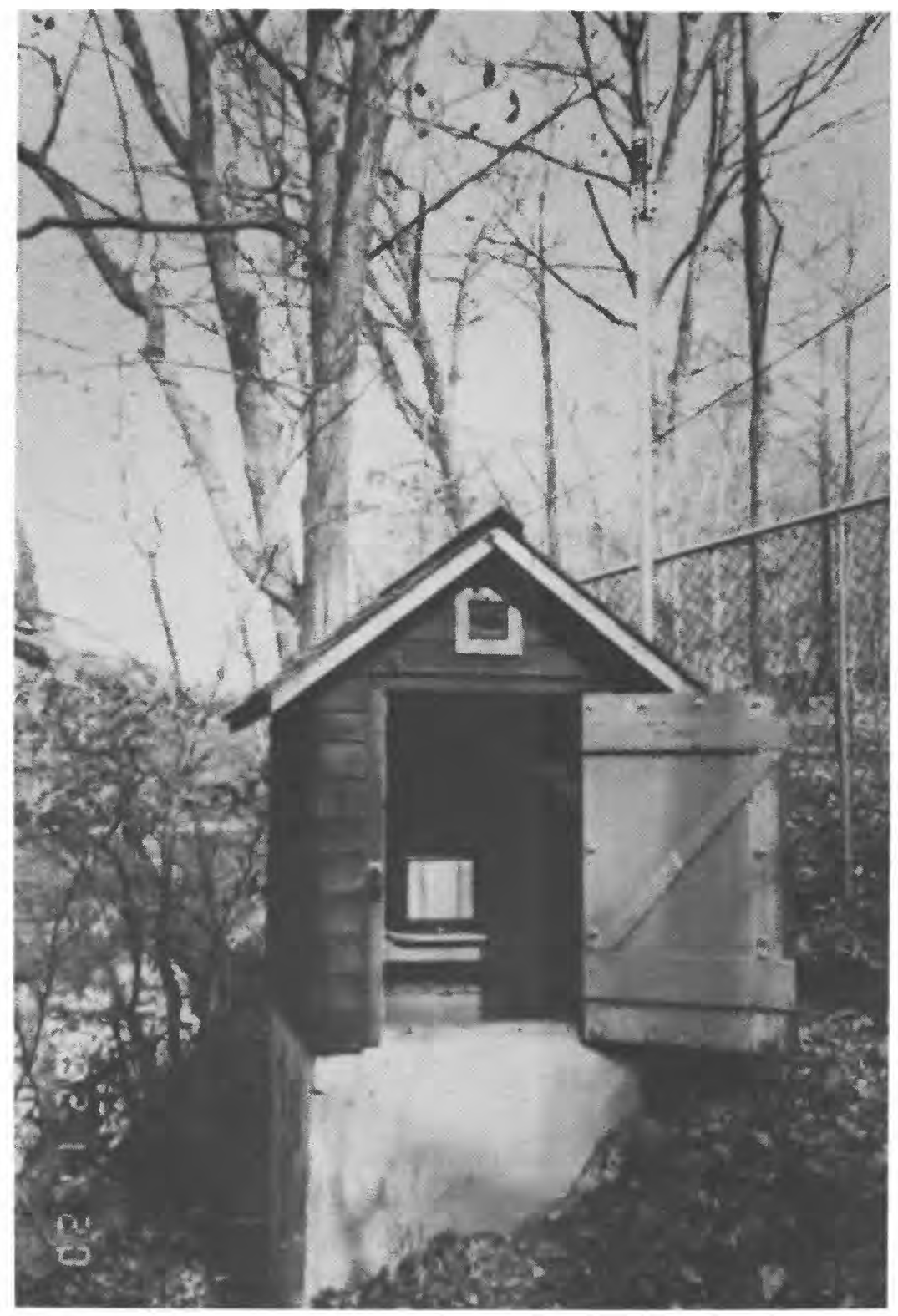

Figure 7.--Gage house at North Branch Raritan River near Far Hills, New Jersey. 


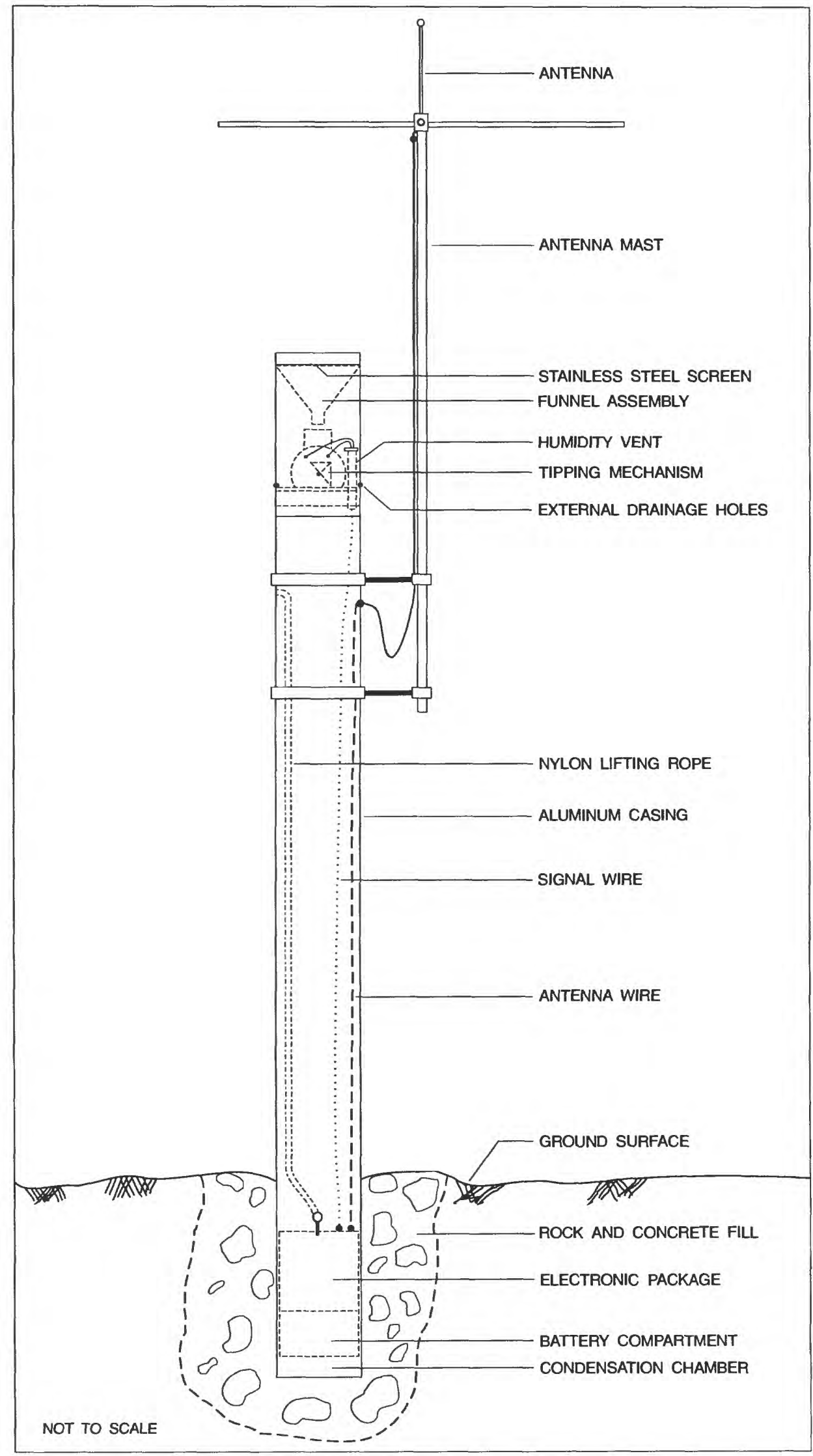

Figure 8.--Diagram of an installed rain gage. (Modified from U.S. National Oceanic and Atmospheric Administration, 1981, fig. 10.) 
transmitted only after a preselected number of tips has occurred (either one or two). Because several sensors may be transmitting at the same time, a delay of 20 seconds is incorporated into the transmitting process. Thus, data for each gage accumulation will not be transmitted more than once during any 20 -second period. At the end of this period, data representing the total gage accumulation will be transmitted to the base station.

A typical float/level streamflow gage is shown in figure 9 . The main component of the gage is the level sensor, which is constructed of a series of reed switches that are triggered when a magnet passes over each one. The magnet is moved by gears attached to a shaft and pulley, which the float turns as it rises with the water surface. A variation of the reed switch is a transistor switch that is affected by magnets passing over it. The size of the gear and pulley and the distance between switch positions determines the precision of the encoder, which measures water level. Sensitivity of the gage is determined by balancing the float/pulley system. The well intake, located in the stream, is designed to mediate the effects of wave action and velocity. Clean-out ports and heavy duty pipes and fittings are used to maintain and ensure proper operation.

Float/level streamflow gages, unlike rain gages, respond to changes in stream level. They are not event recorders that accumulate a total. They are programmed to transmit each change in water level, up or down, and are subject to the transmitter delay. Float/level streamflow gages installed in Somerset County are accurate to 0.01 in. Each gage is equipped with an outside staff or wire-weight gage, as a reference gage and transmits the data to the base-station computers .

An auxiliary gage (crest-stage gage) is located at each site. It is a simple device which will record the peak gage height of a flood crest by floating a small charge of ground cork onto a wood stick contained inside a 2 -in. inside diameter galvanized pipe that is mounted vertically near the stilling well. The wooden stick can be removed easily, and the cork line above the base of the gage can then be measured manually as an independent check of peak stage.

\section{Base Stations}

Base stations can receive data and messages from each other and from a network of 13 base stations, 10 located throughout New Jersey, 2 in New York, and 1 in Pennsylvania. Base stations operated by the USGS are located in the Engineering Division offices in the Somerset County Administration Building and in the USGS office in West Trenton, New Jersey (fig. 10). The remaining bases stations are maintained by the U.S. Army Corps of Engineers.

The USGS base station is designed to be the network poller, sending data to and receiving data from the Somerset County base station and other base stations in the vicinity. In addition to the base station in the county's Engineering Division, a satellite terminal is located in the County communications center. This terminal is connected to the Engineering Division base station by dial-up telephone and can receive all types of data from the network, including alarms. The communications center terminal is manned on a 24-hour basis. The base station at the Somerset County Engineering Division is designed to receive radio-reported gage data. Two 


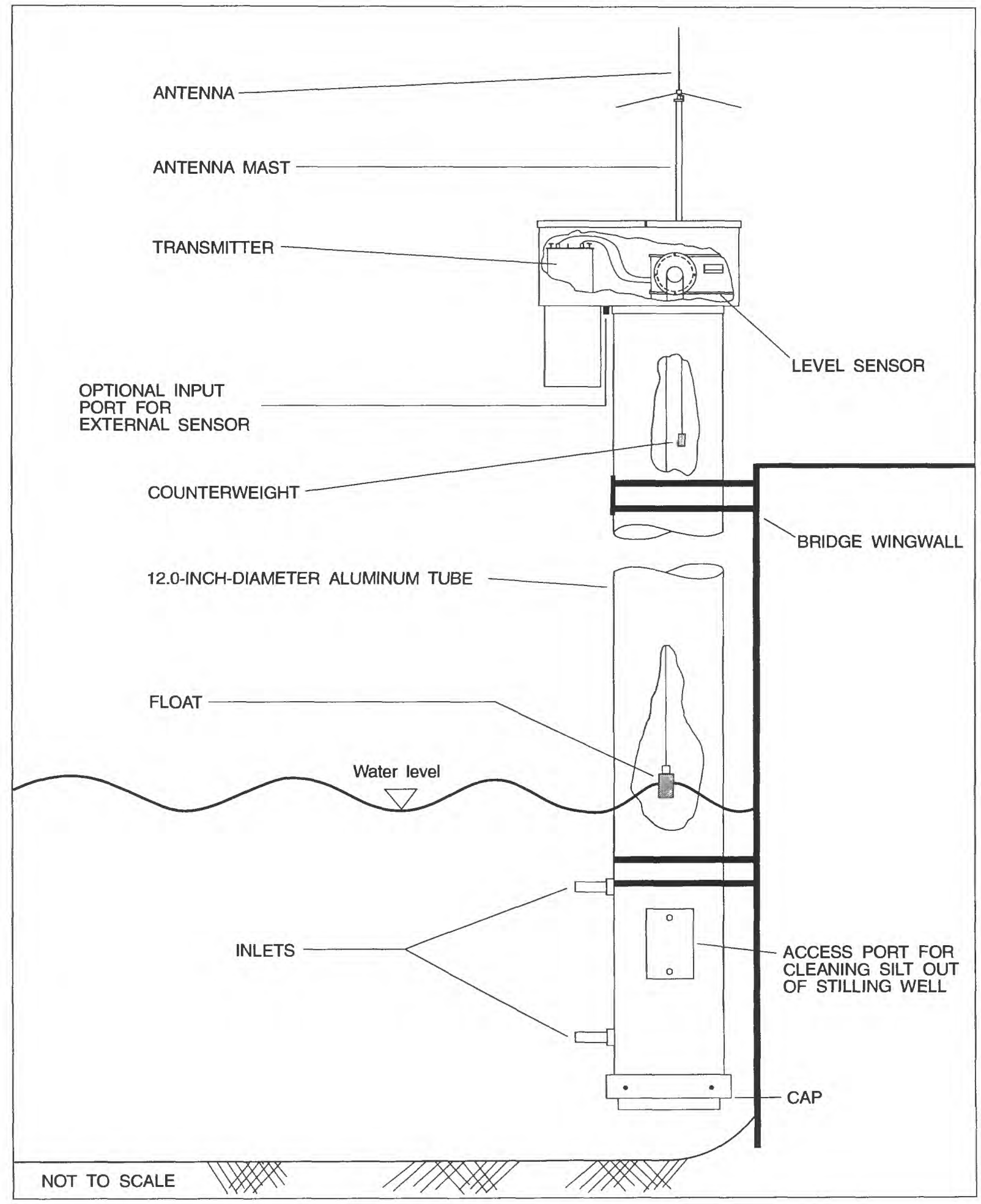

Figure 9.--Diagram of an installed float/level streamflow gage. (Modified from Sierra Misco, Inc., undated.) 


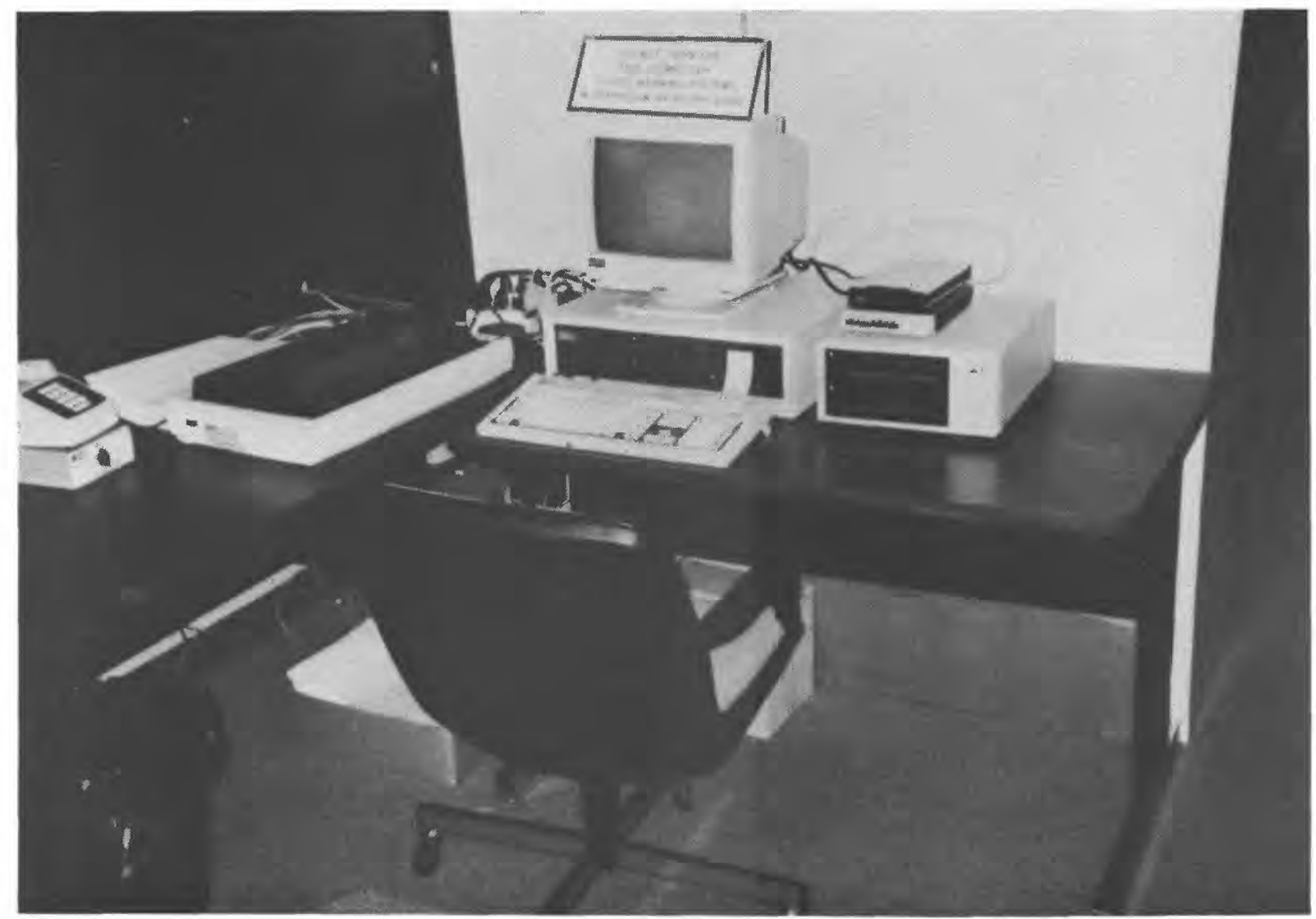

Figure 10.--U.S. Geological Survey base station at West Trenton, New Jersey. 
receivers atop the building are tuned to 169.5 and $171.1 \mathrm{MHz}$ and with one powerful omni antenna (3-decibel gain) can receive direct transmissions and relay transmissions from either of the repeaters, which transmit at 171.1 $\mathrm{MHz}$.

\section{SYSTEM OPERATION}

The Somerset County Flood-Monitoring system uses software produced by Sierra Misco, Inc. ${ }^{1}$ (now marketed by Novalynk Corporation). The software, which is composed of two configurations, Enhanced ALERT (Automated Local Evaluation in Real Time) and an IFLOWS (Integrated Flood Observing and Warning System) interface, allows for real-time collection of data.

The real-time data collection capability is derived from the NWS versions of ALERT and IFLOWS. The basic components of ALERT are (1) automated precipitation and river gages, (2) automated data collection and processing equipment, (3) computerized hydrologic and meteorologic analysis techniques (not used in this monitoring system), and (4) the warning distribution (U.S. National Oceanic and Atmospheric Administration, 1981). The features of IFLOWS that are used in the Somerset County system are (1) two-way transfer of messages and (2) transfer of forecasts, warnings, guidance, and data between the NWS internal communication systems and Somerset County computers (Tabaco, 1986).

The rain gages and streamflow gages are automated. For each $1 \mathrm{~mm}$ of precipitation measured by the rain gages, a radio transmission is sent containing the station identifier and an accumulated precipitation value. The streamflow gages transmit a station identifier and streamflow value at preselected increments. These radio transmissions are received at Somerset County by a radio receiver and microcomputer system that collects and displays the data. The Enhanced ALERT has built-in alarm features which are preset according to individual needs and can be activated by several conditions, such as NWS watches and warnings for storms and floods, streams reaching a pre-selected high or low, river stages rising or falling at preselected rates, failure of a gage to report over a preselected period of time, and important text messages.

The information stored in the data base can be retrieved in the form of tables, plots, or maps. Table 2 is a typical retrieval, listing gage height (in feet) and discharge (in cubic feet per second). These real-time data were transmitted from one of the network's streamflow gages to the West Trenton computer base station on May 31, 1992. Rainfall data collected across Somerset County during a 24-hour period ending at midnight, December 11, 1992, are displayed in typical map format in figure 11. Figure 12 is a plot of gage height (in feet) as a function of time (in days) for the streamflow gage at Stony Brook during November 1-5, 1992. Tables and plots can be created for all types of data including streamflow, precipitation, and battery strength. Plots can be used as overlays to facilitate comparison of data.

1 Use of the firm or trade names in this report is for identification purposes only and does not constitute endorsement by the U.S. Geological Survey. 
Table 2.--Example of computer retrieval of real-time gage-height data collected on May 31, 1992, at Somerville, New Jersey

[Real-time gage height data generated from the Somerset County floodmonitoring system computerized data base stored at the U.S. Geological Survey, West Trenton, New Jersey; feet is gage height. Datum is sea level]

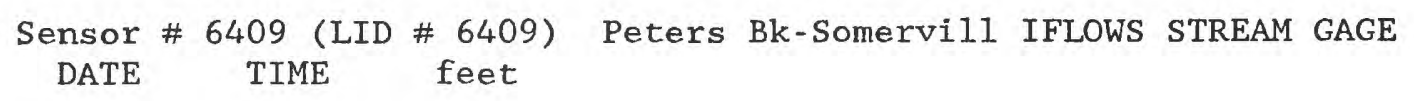




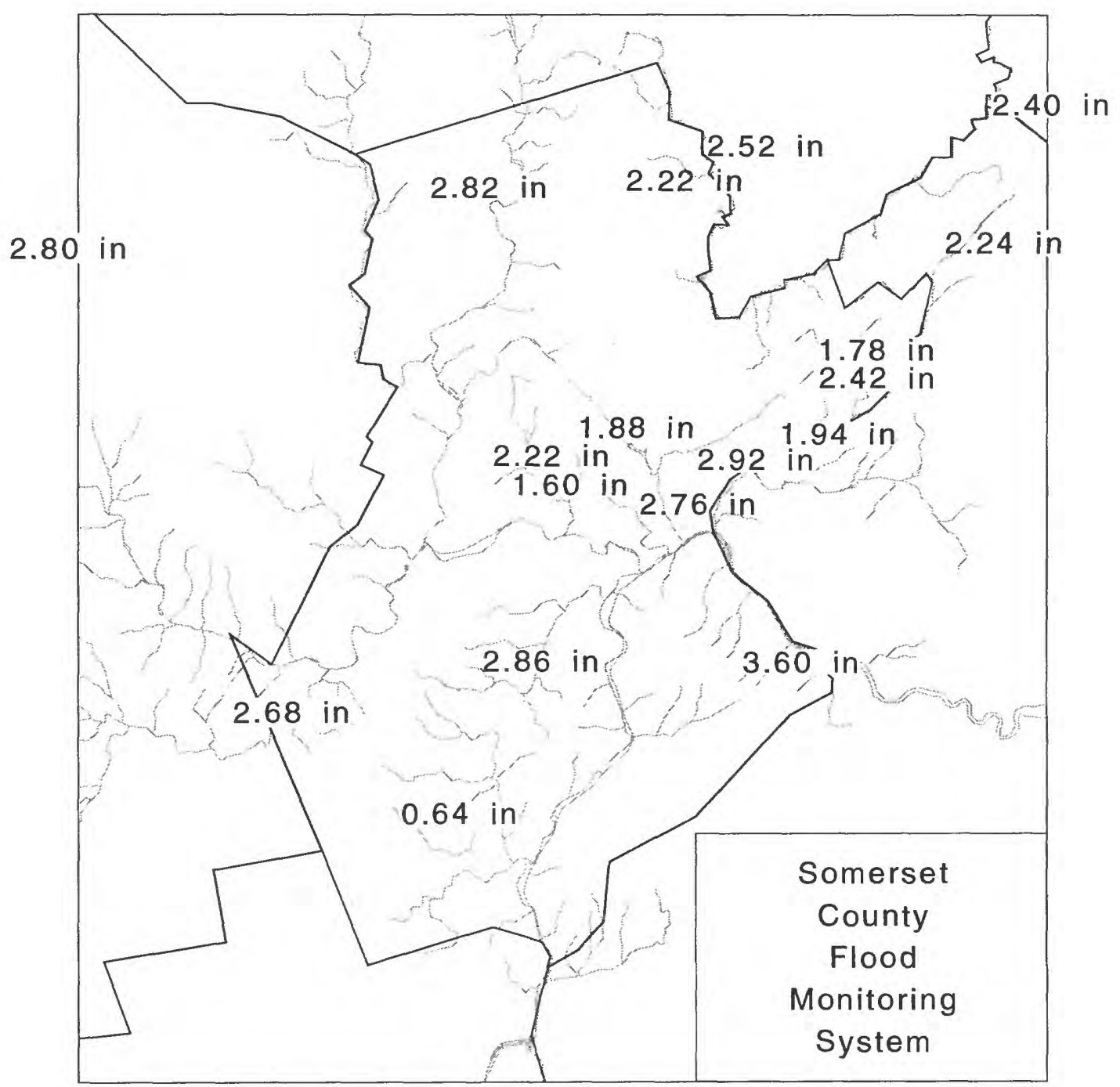

Values for Map \# 12: 24 hours 12/11/92 24:00:00

Figure 11.--Example of computer output showing rainfall data across Somerset County, New Jersey, collected during the 24-hour period, December 11, 1992.

(Rainfall data generated from the computerized data base of the Somerset County flood-monitoring system stored at the U.S. Geological Survey, West Trenton, New Jersey.) 


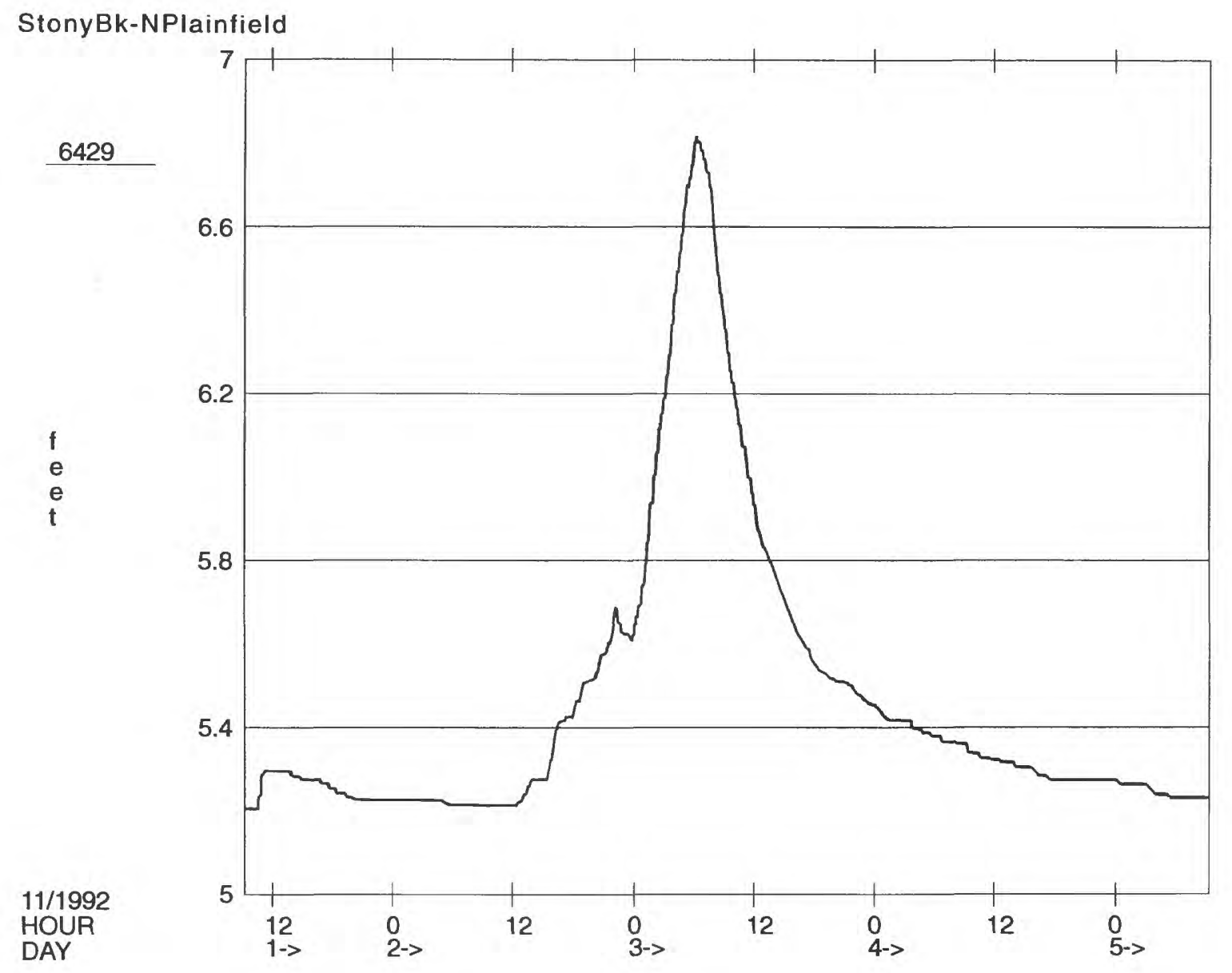

Figure 12.--Example of computer output showing streamflow gage height (in feet) as a function of time (in days) from November 1-5, 1992, at Stony Brook at North Plainfield, New Jersey. (Streamflow gage height generated from the computerized data base of the Somerset County flood-monitoring system stored at the U.S. Geological Survey, West Trenton, New Jersey.) 


\section{SUMMARY}

Severe flooding in Somerset County, New Jersey, during the last 25 years (1968-92) highlighted the need for a local flood-monitoring and warning system. During 1978-90, eight streamflow-gaging stations equipped with rain gages were installed, but data collection was limited to sites upstream from the problem areas. This original network of gages has been expanded by the addition of 14 rain gages and 14 streamflow gages.

Data collection from the original eight gaging stations was limited by telephone telemetry that provided data only when telephoned. When the gage network was expanded, the gages were updated with radio-reporting streamflow gages and rain gages that provide immediate or real-time data. The areal coverage of the basins in the county also was expanded, increasing the probability that floods would be reported quickly.

Many base stations, which are equipped with appropriate microcomputers, monitor streamflow and rainfall data on a 24-hour basis. The network's computer system provides plots and maps to facilitate the analysis of incoming data. The system also sounds alarms to alert operators to extreme rainfall and streamflow conditions, which may indicate that flooding is imminent.

The upgraded Somerset County Flood-Monitoring system provides real-time data collection and increased spatial coverage of rainfall and streamflow conditions throughout Somerset County. The system also improves the monitoring of floods, especially on the small streams, across Somerset County. 
Bauersfeld, W.R., Moshinsky, E.W., and Pustay, E.A, 1992, Water resources data New Jersey, Water Year 1991, Volume 1. Surface-Water Data:

U.S. Geological Survey Water Data Report NJ-91-1, 496 p.

Campbe11, J.B., 1987, Rainfall-runoff data for Somerset County, New Jersey: U.S. Geological Survey Open-File Report 87-384, 161 p.

Fenneman, N.M., 1938, Physiography of eastern United States: New York, McGraw-Hill Book Co., 691 p.

Fulton, J.L., 1990, Application of a distributed-routing rainfall-runoff model to flood-frequency estimation in Somerset County, New Jersey: U.S. Geologica1 Survey Water-Resources Investigations 89-4210, 78 p.

Schopp, R.D., and Burns, R.J., 1991, Local flood warning systems in New Jersey in Inspiration: Come to the headwaters--Proceedings of the Fifteenth Annual Conference of the Association of State Floodplain Managers, June 10-14, 1991, Denver, Colorado, $370 \mathrm{p}$.

Sierra Misco, Inc., undated, Telemetry systems manual: unpublished manual, Berkeley, Calif., Sierra Misco, Inc., 15 chap., unpaginated.

Stankowski, S.J., 1972, Floods of August and September 1971 in New Jersey: New Jersey Department of Environmental Protection Special Report 37, 329 p.

Stankowski, S.J., and Velnich, A.J., 1974, A summary of peak stages and discharges for the flood of August 1973, in New Jersey:

U.S. Geological Survey Open-File Report, 13 p.

Tabaco, Joseph, 1986, IFLOWS: Integrated flood observation and warning system, in Proceedings of the Second International Conference on Interactive Information and Processing Systems for Meteorology, Oceanography and Hydrology of the American Meteorological Society, January 13-17, 1986, Miami, Fla., unpaginated.

U.S. National Oceanic and Atmospheric Administration, 1981, Automated loca1 evaluation in real time--A cooperative flood warning system for your community: Salt Lake City, Utah, National Weather Service, 27 p.

Wolfe, P.E., 1977, The geology and landscapes of New Jersey: New York, Crane, Russak and Company, Inc., 351 p. 